\title{
An Analysis of Pedagogical Beliefs of Teachers at College Level and its Relationship to their Actual Classroom Practices
}

\author{
${ }^{\text {a }}$ Ghazal Khalid Siddiqui, ${ }^{\mathrm{b}}$ Shakeela Shah, ${ }^{\mathrm{c}}$ Shaheen Pasha \\ ${ }^{a}$ Associate Professor, Department of Education, University of Education, Lahore, Pakistan \\ Email: GhazalKhalid@ue.edu.pk \\ ${ }^{\mathrm{b}}$ Assistant Professor, Dept. of Curriculum Development \& Instructions, Faculty of Education, University of Sindh, \\ Jamshoro, Pakistan \\ Email: shakeela@usindh.edu.pk \\ ${ }^{c}$ Assistant Professor, Chairperson, Dept of Special Education, University of Education, Lahore, Pakistan \\ Email: drshaheen.pasha@ue.edu.pk
}

\begin{tabular}{ll}
\hline ARTICLE DETAILS & ABSTRACT \\
\hline History: & Teaching beliefs are the essence of teacher's academic activity. They \\
Accepted 23 March 2021 & contain a set of assumptions or suggestions about the teaching \\
Available Online March 2021 & $\begin{array}{l}\text { profession, teachers, students, and more the process of teaching and } \\
\text { learning. They influence their planning, decision making, work ethic, }\end{array}$ \\
\hline Keywords: & student relationships, evaluation method, material and material \\
Beliefs, Teachers' Pedagogical & selection and among other things, classroom practices. This \\
Beliefs, Teaching Profession, & investigation is aimed to analyze pedagogical beliefs and its relationship \\
Classroom Practices, Students, & to actual classroom practices of teachers at college level. As this study \\
Teachers, Colleges & also reveals the differences among pedagogical beliefs and classroom \\
& practices based on teachers' gender and most importantly explores \\
JEL Classification: & relationship among them at college level. The investigator adopted \\
P36, I21 & quantitative approach and conducted a survey study. Participants were \\
& randomly selected teachers and students from government degree \\
DoI: 10.47067/real.v4i1.134 & colleges of Lahore who provided their responses about pedagogical \\
& beliefs and classroom practices through self-developed questionnaires. \\
& The outcomes shown that educators pedagogical beliefs as well as \\
classroom acts at college level are not significantly correlated to each & other.
\end{tabular}

(C) 2021 The authors. Published by SPCRD Global Publishing. This is an open access article under the Creative Commons Attribution-

NonCommercial 4.0

Corresponding author's email address: GhazalKhalid@ue.edu.pk

\section{Introduction}

Beliefs are inner understanding, principles as well as intentions considered as factual. Although knowledge is called realistic reasoning and understanding (Richardson, 2003). The formation of one's belief system is based on the aggregate of views about physical as well as social world and also beliefs about own-self. Generally they are considered guidelines in a person's life for understanding and comprehending about world around them (Pajares, 1992). Teachers' beliefs are difficult to articulate in 
obscure terms when considering their effective methods (Ertmer, 2005; Hermans, et. al., 2008; Lim, Hills, Choo, Wong, Wu \& Tan 2013).

According to Vartuli (2005) the beliefs of teachers are often irrational, yet they influence decisions about their impressions, character, classroom environment, student interaction and teaching practices. Various teachers have varied beliefs and these frequently affect different classroom activities as well as decision making about teaching activities. Focusing on researches (Clark \& Peterson, 1986; Fang, 1996) educators' teaching believes in addition to classroom practices when interacting students can reveal more insight into how these beliefs serve as the basis for instructional planning. This center may likewise assist with explaining the humiliation that play and learning are isolated substances. This view depends with the understanding that beliefs are best pointers of choices which people make for duration of their life (Dewey, 1933; Bandura, 1986).

According to Denessen (2000), despite the fact that we have believes about nearly everything, believes about pedagogy allude explicitly to understanding, properties as well as suggestions about teachings and learning that end up being consistent with. As Pajares (1992) states all instructors have beliefs about their work, learners, subjects and pedagogical roles as well as duties. This belief system about pedagogy consists of a complex and multidimensional framework of beliefs related to teachinglearning (Hermans, et. al., 2008; Ertmer \& Ottenbreit-Leftwich, 2010). Key believes are the most grounded and thusly generally hard to change since they have different associations with different convictions (Richardson, 1996). Indeed, even fundamental believes about the idea of educating are impervious to change since they have been formed by numerous long periods of involvement and are upheld by solid power and expansive agreement (Ertmer, 2005). When contrasted with believes that are more outsider and as of late shaped are more unique as well as open to change (Fives \& Gill, 2015).

According to Kagan (1992), as instructors acquire insight in the teaching room, their insight turns out to be more credible and in this way their pedagogical believes take on a personal nature that controls impressions, decisions and behaviors. Beliefs are shaped according to individual practices, teaching as well as principles (Vartuli, 2005). These individual believes are important for one's very own viable information, which is the information that should be known and created by instructors. Individual reasonable information is characterized by information on singular encounters, individual chronicles, and subjects. It is a specific method of recreating the past and the aims of things to come to manage the exigencies of the current circumstance. This forms the basis of actions as well as of practices for teachers (Verloop, Van Driel \& Meijer, 2001).

Since numerous instructors invest a ton of energy with youngsters, educators can figure out how to function carefully. Van Manen (2008) portrayed this procedure when instructors comprehend what befalls learners, to comprehend the youngster's encounters, to comprehend the significance of educating for their circumstance, to figure out how and what to do and can accomplish something right. It upholds the idea of underscoring socio-cultural model, recommending that educators and learners cooperate, making a two-dimensional impact in the social setting of the reading class. As the educator executes practice dependent on believes, which thus influences the learning and climate of the learners, this unique experience is disguised by the instructors and the interaction by which it is carried out.

In a survey on instructor believes and classroom practices, Isenberg (1990) proposes that widening the perspective on guidance to incorporate considerations and convictions just as practices may prompt a superior comprehension of the varieties practically speaking seen across singular educators just as the confusion seen when instructors don't reliably utilize suggested instructing 
practices.

Researchers examined (Charlesworth, Hart, Burts \& Hernandez, 1991) the connection between educators' believes and instructional actions. For doing such investigation, researchers had youth instructors completing educator believes and instructional activities questionnaire. The outcomes uncovered positive relationships among formatively suitable believes and exercises and formatively unseemly believes and exercises. The outcomes additionally uncovered that instructors who revealed feeling more in charge of preparation and guidance had all the more formatively fitting scores on the two scales. Additionally, Stipek and Byler (1997) led overviews and perceptions in study classes with 6o montessori educators. They inferred that pre-school and kinder-garten educators' accounted for believes about suitable and successful guidance were altogether related with their noticed instructional practices. Student centered beliefs were emphatically connected with a noticed positive social environment and adversely connected with an accentuation on a fundamental abilities approach. An exploration study looked at (McMullian, Elicker, Geotse, Huang, Lee, Mathers \& Yang, 2006) what preschool instructors announced about their believes comparable to their real instructional processes as inspected by perceptions, educational plan materials, day by day designs, program antiques, and other proof gathered from their teaching surroundings and projects. Results demonstrated that when youngster coordinated free play, rising proficiency, and language advancement exercises were noticed, instructors' self-revealed believes were all the more unequivocally lined up with real practices. In any case, when all the more profoundly organized exercises were noticed, similar to: schedules, preplanned little gathering, and educator coordinated huge gathering learning, instructors all the more firmly supported scholastic educating or fundamental abilities arranged.

A subsequent likely justification the changed discoveries in regards to the connection among believes and practice is that the two builds are once in a while not estimated at a similar degree of consensus or explicitness (Azjen, 1996). For instance, instructor believes might be surveyed in regards to expansive problems (student knowledge as well as advancement), though instructional action perceptions might take a significantly additional explicit center (educators' interaction with youngsters as well as pervasiveness of permitted decision). The degree of idea and examination confound might create misdirecting consequences. Through assessing past examinations, the analysts discovered beliefs of instructors about teaching in addition correlation of such believes to instructional rehearses (Guskey, 1986). By evaluating examination writing, connection among educators' believes as well as instructional actions stayed available toward discussion. Clashes among instructors' believe as well as truth of instructional rehearses might generally revealed in writing. A few investigators (Trigwell \& Prosser, 1996) have discovered textures between educators' believe in relation to instructional acts whereas others might discover irregularities.

Instructors have a bunch of complex believes frameworks that are in some cases not reflected in their instructional procedures for different muddled reasons. The educators' believes can't really massively affect the manner in which they instruct. They are legally necessary to show certain things which might oblige believe. In some cases, instructors need to make up for the disjunction between their own allowances of believes based expectations and the real factors of the instructional limitations. They recommend that what instructors accept and what they really do are very extraordinary. Besides, despite the fact that instructors' believes may change, their practices frequently don't.

Floweday and Schraw (2002) and Ajzen (1985) proposed that believes build up an individual's worth framework that manages life's practices. Another exploration (Trigwell \& Prosser, 1996) found that educator' expressed encouraging goals and training techniques. Few inquiries demonstrate 
instructors' actions couldn't usually steady toward believes. Research analysis (Judson, 2006) discovered an irregularity among educators' purported believes about teaching procedures and real instructional actions. The connection among instructors' believes as well as actions are in certain occurrences determined. Investigators (Abell \& Roth, 1992) struggled for elucidating jumbling among instructors' believes and teaching actions through outer and inner requirements compelling the educator.

Prior studies have noticed that the intricacies of school life can compel educators' capacities to take care of beliefs and give guidance which adjusts their belief system. This proposes that context oriented elements can have amazing effects on educators' believes and influence their instructional rehearses. A few prospects can clarify the puzzle between educators' believes and their real actions. The correlations among pedagogical believes and acts of educators from Lebanon were explored in addition theses believes and acts were compared with financial status of schools, strength of students, achievement standard, instructors' educational foundation extent, educator experience and many other aspects (Faour, 2003). This investigation is contained 135 pre-school and kinder-garten educators. Outcomes displayed an adequate relationship among instructors' believes and practices.

Whether or not teachers' believes are fringe and along these lines individual, verifiable, multifaceted, hypothetically embraced and difficult to express or center, and subsequently predominant, socially loaded, permanent and simple to express (Phipps and Borg, 2009), all educational believes unequivocally impact educators' whole instructional practices. These believes are by and large in arrangement, to a more noteworthy or lesser degree, with contemporary or then again attractive showing standards and, individually, either help or hamper educators and their understudies in accomplishing wanted instructive objectives (Glušac \& Pilipović, 2019). It is as yet an uncertain question whether inadequate or erroneous educator convictions can be changed and how.

It is of most extreme significance for instructors and surprisingly more so for prospective educators, to get mindful of their believes sooner or later of their vocations as educators for two essential reasons - they should be mindful that their believes intensely impact their training and that all those believes that don't work well for them ought to be supplanted or disposed of. The sooner instructors become mindful that they hold a belief that is of no utilization to them or their understudies, the better. Accordingly, those working with prospective instructors should make these instructors stand up to their own believes as a component of the course educational program they educate (Cabaroglu and Roberts, 2000; Wall, 2016), as any endeavor to change their believes once they become rehearsing educators may represent a danger to their character (Glušac \& Pilipović, 2019); many liken a difference in believes with individual change (Yero, 2002). Also, discarding any wrong believes among learners would prompt their more effective expert readiness. Researchers have discovered (Valcke, Sang, Rots and Hermans, 2010) that prospective instructors who neglect to reproduce their pictures of self as instructors fittingly may experience dissatisfactions adequately extreme to end their instructional profession before they truly gotten an opportunity to start.

Educators' believes and practices altogether vary contingent upon schools' commercial position, student strength and educational standard. Educators' degree of common schooling, preparing, age, pay, and chief's help were additionally identified with believes and rehearses of instructors. Two English language educators' believes were tested as well as instructional acts (Wang, 2006). Information were gathered with two semi-organized meetings as well as 14 class-perceptions. The information proposed that the two instructors' believes and practice were to a great extent reliable as far as showing exercises and educating techniques. 
Al-abdulkareem (2004) examined Saudi educators' believes about science and instructing, in addition to determine how educators perceive educational transformation, and change in training. The participants were educators and administrators. The conclusions showed that educators in science classrooms do not really practice their pedagogical believe. Chou (2008) led an examination dependent with the understanding that instructors are profoundly affected by believes. He researched the believes about showing perusing among forty two college educators. The level of errors or textures between educators' believes and their useful encouraging exercises were investigated. The discoveries showed that there were no huge contrasts between the members' believe and their instructional procedures.

Shun (2008) analyzed instructors' teaching believes and their relations to teaching techniques. Educators of forty schools of Singapore took part in examination. The outcomes revealed that there was very little fluctuation in instructors' teaching believes, in addition to the utilization of instructional technique. Phillips (2009) researched believes and practices of secondary school social study educator through her teaching. Outcomes revealed her instructional procedures changed with the change in pedagogical believes as well as goals with the passage of time and adjusted to school environment as well as learners needs. The investigation recommends that notwithstanding difficulties that she experienced, this educator rehearsed in manners that were steady with her believes.

The intent behind an investigation (Bisland, O'Conner and Malow-Iroff, 20o9) existed exploration of pedagogical believes of community study instructors in USA and degree to which instructors practiced believes. The examination tracked down no evidence of the connection between educators' pedagogical believes and useful instructional processes. Harcarik (2009) researches connection among 5th class instructors' information as well as pedagogical believes and their relationship to instructional procedures. Quantitative information were gathered through a survey. To give an exhaustive image of the 5th grade educators' information, pedagogical believes, and selfdescribed instructional practices on identifying with social study. The discoveries of this examination demonstrate a connection among educators' pedagogical believes as well as educators' self-described instructional actions.

Some researchers (Hedrick, Harmon \& Linerode, 2004) examine pedagogical believes and yeaching acts of instructors in elementary schools just as their utilization of educators' manuals. Utilizing a self-describing questionnaire to gauge these believes and actions, they discovered some contradiction between what educators accept about pedagogical believes and their real teaching practices. While all educators overviewed held numerous pedagogical believes and practices in like manner, their beliefs as well as actions were significantly influenced by grade level, financial status and many other factors.

There is minimum consideration of researchers toward gender orientation contrasts in instructors' pedagogical believes, the connection between male and female educator believes and practices. It is broadly concurred that educators play important role in learners' academic life (CochranSmith and Zeichner, 2005; Tatlah, 2015). By investigating gender differences, apparently instructors' pedagogical believes are a significant variable. As per Fennema (1990), experiences into instructors' pedagogical believes may prompt further comprehension of gender orientation contrasts in math. For instance, male and female educators may hold distinctive pedagogical believes about understudies' learning. This may have impact on their classroom instruction, which thus can influence understudies' believes and accomplishment. Contrasts in educators' teaching methodologies may likewise affect male and female understudies, separately. It is likewise an inquiry whether the impact of both instructors' pedagogical believes and gender may impact learners' learning adapting in an unexpected way. 
In a new report dependent on instructional perceptions in Norwegian schools, no distinctions were enlisted in male and female instructors' association of guidance in various teaching aspects, including math (Haug, 2010; Tatlah,2014). Notwithstanding, educators' pedagogical believes identified with understudies' learning and advancement have gotten little consideration (Buehl and Alexander, 2009).

It is seen through exploring the past examinations that they don't contain any investigation that takes attention at pedagogical beliefs of the instructors at college level, in spite of the fact that recognizing the educational believes of school educators may prompt understanding the elements that influence their instructional acts, which permits the arrangement of a viable system for instructing and to contribute in coordinating more accentuation on showing particularly in the essential cycle. Subsequently, this examination came to break down the teaching believes of instructors at college level in the fundamental cycle and the level of their instructional acts of these believes, just as unveiling the connection between the teaching beliefs of educators and their instructional acts.

\section{Conceptual Framework}

Present inquiry is aimed to analyze educators' pedagogic beliefs as well as its relationship to real teaching processes at college level. Beliefs are inner understanding, principles as well as intentions considered as factual. Although knowledge is called realistic reasoning and understanding. According to Vartuli (2005) the beliefs of teachers are often irrational, however they affect decisions about their impressions, character, learning environment, student interaction and teaching practices. Various teachers have varied beliefs and these frequently affect different classroom activities as well as decision making about teaching activities. Focusing on researches (Clark \& Peterson, 1986; Fang, 1996) pedagogic theories of educators and classroom practices when interacting students can reveal more insight into how these beliefs serve as the basis for instructional planning. Current investigation is focusing on exploring the correlations among educators' pedagogical beliefs and their real instructional acrions as well as finding teachers' gender differences regarding pedagogical beliefs plus classroom practices at college level. Conceptual framework of inquiry is given below (Figure 1).
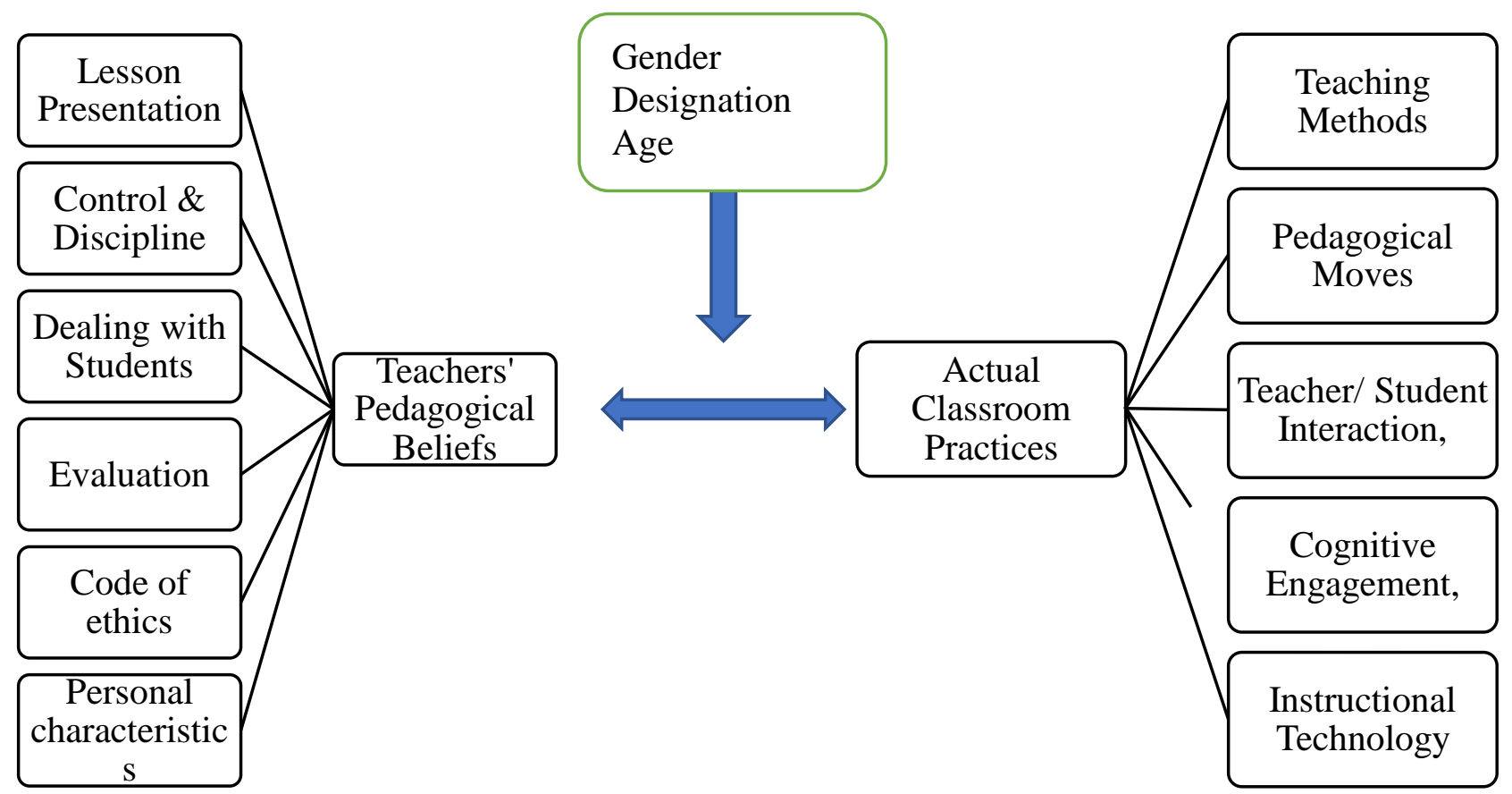

Figure 1 Conceptual Framework for Relationship between Pedagogical Beliefs and Classroom Practices of Teachers 
Current investigation answered these research questions:

- Is there any difference in pedagogical beliefs of teachers at college level based on their gender?

- Is there any difference in male and female students' perceptions for teachers' classroom practices?

- Is there any relationship between pedagogical beliefs and classroom practices of teachers at college level?

\section{Research Procedure}

As this study reveals the differences among pedagogical beliefs and classroom practices based on teachers' gender and most importantly explores the relationship among these beliefs and instructional practices at college level. The investigator adopted quantitative approach and conducted a survey study. Teachers as well as students from government degree colleges of Lahore were participated in investigation. Due to large population, they were selected randomly. First of all, nine male and female degree colleges were randomly selected and then sixty three male and female teachers were selected from these colleges. The teachers were selected from two departments Education and English. The detail of the teachers' designation, department, age and gender is given below.

Table 1 Details of Sample of Teachers $(\mathrm{N}=63)$

\begin{tabular}{|l|l|c|c|}
\hline Variables & levels & Frequency & Percentage \\
\cline { 1 - 4 } Gender & Male & 9 & 14 \\
\cline { 1 - 3 } & Female & 54 & 86 \\
\hline \multirow{2}{*}{ Designation } & Associate Professor & 16 & 25 \\
& Assistant Professor & 25 & 40 \\
& Lecturer & 22 & 35 \\
\hline Department & English & 47 & 75 \\
\hline Age (years) & Education & 16 & 25 \\
\hline & $25-35$ & 11 & 17 \\
& $35-45$ & 27 & 43 \\
& $>45$ & 25 & 40 \\
\hline
\end{tabular}

For the sample of the students, ten to eleven students were randomly selected with respect to each teacher's classroom, hence total male and female students chosen from English and Education departments were six hundred and sixty seven (667). The detail of students' age, gender, discipline is given below (table 1a).

Table 1a Details of the Sample of Students $(\mathrm{N}=667)$

\begin{tabular}{|l|l|c|c|}
\hline Variables & Levels & Frequency & Percentage \\
\hline Gender & & & 25 \\
\hline & Male & 166 & 75 \\
\hline & Female & 501 & 88 \\
\hline Discipline & & & 12 \\
\hline & English & 585 & \\
\hline Age & Education & 82 & 28 \\
\hline & & & 53 \\
\hline & $14-16$ & 187 & 19 \\
\hline & $17-19$ & 356 & 124 \\
\hline
\end{tabular}


With the purpose of analyzing teachers' pedagogical beliefs at college level, researcher has developed a questionnaire. The literature related to teachers' pedagogical beliefs was keenly reviewed as well as by examining previous researchers' tools for determining the pedagogical beliefs of teachers. This questionnaire includes thirty items spread across six domains; lesson presentation, control and discipline, dealing students, evaluation, ethics and personal characteristics. Likewise an additional questionnaire was designed to explore students' opinions about teachers' actual classroom practices. It includes twenty five items spread across five domains; teaching methods, pedagogical moves, teacherstudent interaction, cognitive engagement, and instructional technology.

For determining whether these questionnaires are valid, content validity was ensured by experts. The reliability of the questionnaires was determined by calculating Cronbach's alpha. The alpha level of teachers' pedagogical beliefs questionnaire was 0.58 and for classroom practices questionnaire was 0.63 , expressing significantly reliability.

All the data were collected and analyzed descriptively by the researcher. At first stage teachers' pedagogical beliefs were collected and then their actual practices were confirmed by their respective students.

\section{Results and Discussion}

The first research question: is there any difference in pedagogical beliefs of teachers at college level based on their gender? To answer this question, a t-test was applied to differentiate the teachers' pedagogical beliefs based on their gender (table 2).

Table 2 Differences of male and female teachers on pedagogical beliefs

\begin{tabular}{|c|c|c|c|c|c|c|c|}
\hline \multicolumn{8}{|l|}{ Gender } \\
\hline \multirow[b]{2}{*}{ Domains } & \multicolumn{2}{|l|}{ Male } & \multicolumn{2}{|l|}{ Female } & \multicolumn{3}{|c|}{ Independent Samples t - test } \\
\hline & $M$ & $S D$ & $M$ & $S D$ & $t$ & $d f$ & $p$ \\
\hline Lesson Presentation & 4.27 & .46 & 4.42 & .28 & -1.27 & 61 & .207 \\
\hline Control and Discipline & 4.44 & .33 & 4.29 & .48 & .932 & 61 & .355 \\
\hline Dealing with Students & 4.20 & .53 & $4 \cdot 37$ & .39 & -1.125 & 61 & .265 \\
\hline Evaluation & 4.28 & .49 & 4.47 & 1.16 & -.460 & 61 & .647 \\
\hline Code of Ethics & 4.44 & .45 & 4.61 & .33 & -1.371 & 61 & .175 \\
\hline Personal Characteristics & 4.44 & .60 & 4.49 & .39 & -.333 & 61 & .741 \\
\hline
\end{tabular}

The results showed there is no significant difference in male and female teachers' pedagogical beliefs at $\mathrm{p}>.05$. There are six domains presenting instructors' teaching beliefs. The mean score for male teachers ranges from 4.20 to 4.44 and standard deviation from .33 to .6o. The mean score of female teachers ranges from 4.29 to 4.61 and standard deviation from .28 to 1.16 .

The second research question: is there any difference in male and female students' perceptions for teachers' actual classroom practices? To answer this question, a t-test analysis was applied to differentiate perceptions of students regarding their teachers' classroom practices (table 3 ). 
Table 3 Perceptions of students on teachers' classroom practices

\begin{tabular}{|l|l|l|l|l|l|l|c|}
\hline Gender & \multicolumn{1}{l|}{ Male } & \multicolumn{1}{l|}{ Female } & \multicolumn{3}{l|}{ Independent Samples t - test } \\
\hline Domains & $M$ & $S D$ & $M$ & $S D$ & $t$ & $d f$ & $p$ \\
\hline & 2.80 & .49 & 2.62 & .62 & 3.347 & 665 & .001 \\
\hline Teaching Methods & 2.70 & .43 & 2.87 & .51 & -3.847 & 665 & .000 \\
\hline Pedagogical Moves & 2.68 & .65 & 2.88 & .64 & -3.550 & 665 & .000 \\
\hline Teacher/ Student interaction & 2.56 & .46 & 2.65 & .60 & -1.675 & 665 & .094 \\
\hline Cognitive Engagement & 2.29 & .42 & 2.31 & .51 & -.481 & 665 & .630 \\
\hline Instructional Technology & & & & & & \\
\hline
\end{tabular}

The findings showed that there was a huge contrast in male and female learners' discernments with respect to their instructors' teaching acts on three areas; teaching methods, pedagogical moves and student-teacher interaction $(\mathrm{p}<.05)$. While there was no huge contrast in cognitive engagement and instructional technology $(\mathrm{p}>.05)$.

For finding, is there any correlation among instructors' pedagogical beliefs and their real classroom practices at college level, Pearson correlation was applied.

Table 4 Correlation coefficient of the pedagogical beliefs and the classroom practices

\begin{tabular}{|c|c|c|c|}
\hline \multicolumn{4}{|l|}{ Correlations } \\
\hline & & $\begin{array}{l}\text { Teachers Pedagogical } \\
\text { Beliefs }\end{array}$ & Classroom Practices \\
\hline \multirow{3}{*}{$\begin{array}{l}\text { Teachers } \\
\text { Beliefs }\end{array}$} & Pearson Correlation & 1 & -.109 \\
\hline & Sig. (2-tailed) & & .395 \\
\hline & $\mathrm{N}$ & 63 & 63 \\
\hline \multirow{3}{*}{ Classroom Practices } & Pearson Correlation & -.109 & 1 \\
\hline & Sig. (2-tailed) & .395 & \\
\hline & $\mathrm{N}$ & 63 & 667 \\
\hline
\end{tabular}

Findings revealed that there was no significant relationship among instructors' pedagogical beliefs and their real instructional acts at $r=-.109, n=63$ and $p>.05$ (table 4).

Table 4a Correlation coefficient of the domains of pedagogical beliefs and the classroom practices

\begin{tabular}{|l|c|c|c|c|c|}
\hline Correlations \\
\hline \multicolumn{1}{|c|}{ Domains } & $\begin{array}{c}\text { Teaching } \\
\text { Methods }\end{array}$ & $\begin{array}{c}\text { Pedagogical } \\
\text { Moves }\end{array}$ & $\begin{array}{c}\text { Teacher/student } \\
\text { Interaction }\end{array}$ & $\begin{array}{c}\text { Cognitive } \\
\text { Engagement }\end{array}$ & $\begin{array}{c}\text { Instructional } \\
\text { technology }\end{array}$ \\
\hline Lesson Presentation & -.088 & -.011 & -.087 & -.223 & -.156 \\
\hline Control and Discipline & .109 & -.185 & -.051 & -.230 & -.105 \\
\hline Dealing with students & -.100 & -.223 & .073 & -.068 & -.206 \\
\hline Evaluation & -.180 & .034 & .043 & -.145 & -.158 \\
\hline Code of Ethics & .075 & $-.313^{*}$ & $-.258^{*}$ & -.247 & $-.280^{*}$ \\
\hline Personal Characteristics & .116 & -.042 & .092 & .012 & -.151 \\
\hline
\end{tabular}


Results showed that there was negative and not significant connection among teaching methods, pedagogical moves, teacher-student interaction, cognitive engagement, instructional technology and lesson presentation at $\mathrm{r}=-.087$ to $-.223, \mathrm{p}>.05$. There was no huge connection among domains of classroom practices and control and discipline at $\mathrm{r}=-.051$ to $-.230, \mathrm{p}>.05$. There was no critical connection among classroom practices and dealing students at $\mathrm{r}=-.068$ to $-.223, \mathrm{p}>.05$. There was no critical connection among instructional practices and evaluation at $\mathrm{r}=.034$ to $-.180, \mathrm{p}>.05$. There was no critical connection among classroom practices and code of ethics at $\mathrm{p}>.05$. There was a critical negative connection among pedagogical moves teacher-student interaction and code of ethics ( $\mathrm{r}=$ $.258, \mathrm{p}<.05)$, instructional technology and code of ethics $(r=-.280, \mathrm{p}<.05)$. There was no critical connection among classroom practices (domains) and individual characteristics at $\mathrm{r}=.012$ to $-.151, \mathrm{p}>$ .05 (table 4a).

This research study is aimed at analysis of pedagogical beliefs of teachers and its relationship to their actual classroom practices at college level. To fulfill this aim three research questions were designed as: is there any difference in pedagogical beliefs of teachers at college level based on their gender, is there any difference in male and female students' perceptions for teachers' actual classroom practices and is there any correlation among teachers 'pedagogical beliefs and real classroom practices at college level?

Study findings showed that pedagogical beliefs of instructors are not different from each other at college level based on their gender. The pedagogical beliefs of male and female teachers at college level are not significantly different from each other and it is consistent with findings of Haug (2010) in literature. The findings revealed that the belief in pedagogical beliefs has risen in all domains of teachers, which may be due to what Pajares (1992) wrote about instructors who had a belief system. Thus the parts of the system were coherent and constant with each other, which is why educators considered the assessment of teachers' beliefs to be high in all domains. This encouraged teachers to create a comprehensive picture of teaching principles in all aspects of instructional procedures.

There is no significant relationship between teachers' pedagogical beliefs and their actual classroom practices at college level and this outcome concurs to consequence of various studies (AlAbdulkareem, 2004; Chou, 2008; Shun, 2008; Bisland, et. al., 2009) presumed that there is no connection between the educators' beliefs and classroom practices. Additionally this study revealed that instructors' pedagogical believes are contradicted with actual classroom practices and it concurs to the findings of previous study in literature (Hedrick, et. al., 2004) demonstrated to the presence of logical inconsistency between believes and practices of instructors.

\section{Conclusion}

Current discoveries have added to the writing on the beliefs of college educators and classroom practices. It is inferred that there is no critical connection among academic pedagogical beliefs and actual instructional acts of instructors at college level. There is an inconsistency among instructors' articulated teaching beliefs and their real instructional acts. This examination might be helpful for future exploration in regards to proficient improvement activities. Specifically, the focal point of projects and studies for instructor direction ought to remember information for educators' instructional and viable teaching standards. Subsequently, there is a need to lead more investigations to confirm the connection between the belief systems of educators and their classroom practices.

\section{Recommendations}

Current investigation was conducted to reveal is there any correlation among educators' 
instructional theories and real teaching actions at college level. The approach was quantitative analysis. It is recommended that future researchers should conduct research on other aspects of pedagogical beliefs and classroom practices of school and university educators. More reserch should be done to find the influence of other variables on educators' classroom practices as well as it is suggested to conduct qualitative and qualitative studies to more keenly revealing teachers' pedagogical beliefs and instructional practices. Future researchers should conduct interviews and observations of teachers as well as of students at different levels. It is also suggested to train teachers for implementing actually their pedagogical beliefs in classrooms at different academic levels.

\section{References}

Abell, S. \& Roth, M. (1992). "Constraints to teaching elementary science: A case study of a science enthusiast student teacher". Science Education, 76 (6) p. 581-596.

Al-Abdulkareem, S. (2004). Investigating Science Teachers' Beliefs about Science and Science Teaching: Struggles in Implementing Science Education. Reform in Saudi Arabia. Ph.D theses Submitted to West Virginia University.

Azjen, I. (1996). The directive influence of attitudes on behavior. In P. M. Gollwitzer \& J. A. Barhg (Eds.), The psychology of action: Linking cognition and motivation to behavior. New York, New York: The Guilford Press.

Bandura, A. (1986). Social foundations of thought and actions: A social cognitive theory. Englewood Cliffs, NJ: Prentice-Hall.

Bisland, B., O’Connor, E. \& Malow-Iroff, M. (2009). "Beliefs and Issues in Social Studies Instructional Practices: A Case Study of Alternatively Certified Elementary Teachers". Paper presented at the College and University Faculty Assembly of the National Council for the Social Studies, Atlanta, GA., November 11.

Buehl, M. M., \& Alexander, P. A. (2009). Beliefs about learning in academic domains. In K.R. Wentzel \& A. Wigfield (Eds.), Handbook of motivation at school (479-501). NY: Routledge.

Cabaroglu, N., \& Roberts, J. (2000). Development in student teachers' pre-existing beliefs during a 1year PGCE programme. System, 28(3), 387-402.

Charlesworth, R., Hart, C. H., Burts, D., \& Hernandez, S. (1991). Kindergarten teachers' beliefs and practices. Early Child Development and Care, 70, 17-35.

Chou, Y. (2008). "Exploring the reflection of teachers' beliefs about reading theories and strategies on their classroom practices”. Fengchia Journal of Humanities and Social Sciences, 16, p 183-216.

Clark, C. M., \& Peterson, P. L. (1986). Teachers' thought processes. In M.C. Wittrock (3rd ed.), Handbook of research on teaching (pp. 255-296). New York: Macmillan.

Cochran-Smith, M., \& Zeichner, K. M. (2005). Studying teacher education: The report of the AERA-Panel on Research and Teacher Education. Wahwah: Lawrence Erlbaum.

Denessen, E. (2000). Opvattingen over onderwijs (Beliefs about education). Apeldoorn: Garant.

Dewy, J. (1933). How we think. Boston: D. C. Heath.

Ertmer, P. A. (2005). Teacher pedagogical beliefs: The final frontier in our quest for technology integration?. Educational technology research and development, 53(4), 25-39.

Ertmer, P. A., \& Ottenbreit-Leftwich, A. T. (2010). Teacher technology change: How knowledge, confidence, beliefs, and culture intersect. Journal of Research on Technology in Education, 42, $255^{-284}$.

Fang, Z. (1996). A review of research on teacher beliefs and practices. Educational research, 38(1), 4765.

Faour, B. (2003). Early childhood Teachers in Lebanon: Beliefs and practices. Ph. D theses. School of education. University of Leicester. UK.

Fennema, E. (1990). Teachers' beliefs and gender differences in mathematics. In E. Fennema \& G. C. Leder (Eds.), 
Mathematics and gender (169-187). New York: Teachers' College Press. Friedel, J. M., Cortina, K. S., Turner, J. C., \& Midgley, C. (2007). Achievement goals, efficacy beliefs and coping strategies in mathematics: The role of perceived parent and teacher goal emphases. Contemporary Educational Psychology, 32, 434-458.

Fives, H., \& Gill, M. G. (Eds.). (2015). International handbook of research on teachers' beliefs. New York: Routledge, Taylor \& Francis.

Flowerday, T. \& Schraw, G. (2002). "Teacher beliefs about instructional choice: A phenomenological study". Journal of Educational Psychology, 92 p.634-645.

Glušac, T. L., \& Pilipović, V. B. (2019). English language student teachers' pedagogical beliefs: Susceptibility to change and sources of change.Zbornik radova Filozofskog fakulteta $\mathrm{u}$ Prištini, 49(1), 69-88.

Guskey, T. R. (1986). Staff development and the process of teacher change. Educational researcher, 15(5), 5-12.

Harcarik, M. (2009). Fifth-Grade Teachers' Social Studies Knowledge and Beliefs and Their Relationship To Classroom Practices. Unpublished Doctoral Thesis. The University of Florida, USA.

Haug, P. (2010). Korleis kvinnelege og mannlege lærarar underviser [How female and male teachers teach]. Bedre skole, 4, 24-28.

Hedrick, B., Harmon, M. \& Linerode, M. (2004). "Teachers' Beliefs and Practices of Vocabulary Instruction with Social Studies Textbooks in Grades 4-8". Reading Horizons, 45(2), 103-125.

Hermans, R., Tondeur, J., Van Braak, J., \& Valcke, M. (2008). The impact of primary school teachers' educational beliefs on the classroom use of computers. Computers \& education, 51(4), 14991509.

Isenberg, J. P. (1990). Teachers' thinking and beliefs and classroom practice. Childhood Education, 66(5), 322-327.

Judson, E. (2006). "How teachers integrate technology and their beliefs about learning: Is there a connection"? Journal of Technology and Teacher Education. 14 p.581-597.

Kagan, D. M. (1992). Implication of research on teacher belief. Educational psychologist, 27(1), 65-90.

Lim, K. S., Hills, M. D., Choo, W. Y., Wong, M. H., Wu, C., \& Tan, C. T. (2013). Attitudes toward epilepsy among the primary and secondary school teachers in Malaysia, using the public attitudes toward epilepsy (PATE) scale. Epilepsy research, 106(3), 433-439.

McMullan, M., Elicker, J., Goetze, G., Huang, H., Lee, S., Mathers, C., Yang, H. (2006). Using collaborative assessment to examine the relationship between self-reported beliefs and the documentable practices of preschool teachers. Early Childhood Education Journal, 34, 81-91.

Pajares, M. F. (1992). Teachers' beliefs and educational research: Cleaning up a messy construct. Review of educational research, 62(3), 307-332.

Phillips, M. (2009). "Beginning teacher beliefs and wise practices: A case study of a high school social studies teacher". Ph.D dissertation, University of Florida.

Phipps, S., \& Borg, S. (2009). Exploring tensions between teachers' grammar teaching beliefs and practices. System, 37(3), 380-390.

Richardson, V. (2003) 'Preservice teachers' beliefs', in Raths, J. and McAninch, A.C. (eds.) Teacher Beliefs and Classroom Performance: The Impact of Teacher Education Greenwich, Connecticut: Information Age, pp. 1-22.

Shun, L. (2008). Teacher Beliefs and their implications for enhancing instructional practices. Center for Research in Pedagogy and Practice. Singapore.

Stipek, D. J., \& Byler, P. (1997). Early childhood education teachers: Do they practice what they preach? Early Childhood Quarterly, 12, 305-326.

Trigwell, K., \& Prosser, M. (1996). Changing approaches to teaching: A relational perspective. Studies in higher education, 21(3), 275-284.

Tatlah, I. A. (2015). Effect of leadership behaviour and school organizational health on 
students'achievement. Lahore: (Unpublished Doctoral Thesis) University of Management and Technology, Lahore.

Tatlah, I. A., Iqbal, M. Z., Amin, M., \& Quraishi, U. Q. (2014). Effect of leadership behaviour of principals on students' academic achievement at secondary level: A comparison of leaders and teachers perceptions. Journal of Research and Reflections in Education, 1-12.

Valcke, M., Sang, G., Rots, I., \& Hermans, R. (2010). Taking prospective teachers' beliefs into account in teacher education. In International encyclopedia of education (pp. 622-628). Elsevier.

Van Manen, M. (2008). Pedagogical sensitivity and teachers' practical knowing-inaction. Peking University Education Review, 6(1), 2-20.

Vartuli, S. (2005). Beliefs: The heart of teaching. YC Young Children, 6o(5), 76.

Verloop, N., Van Driel, J., Meijer, P. (2001). Teacher knowledge and the power base of teaching. International Journal of Educational Research, 35(5), 441-461.

Wall, G. C. (2016). From Student to Teacher: Changes in Preservice Teacher Educational Beliefs throughout the Learning-to-Teach Journey. An International Journal of Teachers' Professional Development, 20, 364-379.

Wang, W. (2006). Exploring teacher beliefs and practice in the implementation of a new English language curriculum in China: Case studies. APERA conference. University of Hong Kong.

Yero, J. L. (2002). Teaching in Mind: How Teacher Thinking Shapes Education. Hamilton, MT: MindFlight Publishing. 